\title{
1 Macronutrients modulate resistance to infection and immunity in Drosophila
}

2

3 Fleur Ponton ${ }^{a}$, Juliano Morimoto ${ }^{a}$, Katie Robinson ${ }^{b}$, Sheemal S Kumara ${ }^{a}$ Sheena Cotterc, 4 Kenneth Wilson ${ }^{d}$, and Stephen J Simpson ${ }^{\text {b }}$

aDepartment of Biological Sciences, Macquarie University, Sydney, Australia NSW 2109

${ }^{b}$ Charles Perkins Centre and School of Life and Environmental Sciences, The University of 10 Sydney, NSW 2006, Australia

${ }^{\mathrm{c}}$ School of Life Sciences, University of Lincoln, Lincoln, United Kingdom

*Corresponding author

Dr Fleur Ponton

17 Macquarie University 


\section{ABSTRACT}

- Immunity and nutrition are two essential modulators of individual fitness

- However, while the implications of immune function and nutrition on an individual's lifespan and reproduction are known, the interplay between feeding behaviour, infection, and immune function, remains poorly understood.

- In this study, we used the fruit fly, Drosophila melanogaster, to investigate how infection through septic injury modulates nutritional intake, and how macronutrient balance affects survival to infection by the pathogenic Gram-positive bacterium Micrococcus luteus.

- Our results show that infected flies maintain carbohydrate intake, but reduce protein intake, thereby shifting from a protein-to-carbohydrate (P:C) ratio of $\sim 1: 4$ to $\sim 1: 10$ relative to noninfected and sham-infected flies.

- Strikingly, we found that the proportion of flies dying after M. luteus infection was significantly lower when flies were fed a low-P high-C diet, revealing that flies shift their macronutrient intake as means of nutritional self-medication against bacterial infection.

- This is likely due to the effects of macronutrient balance on the regulation of the constitutive expression of innate immune genes, as a low-P high-C diet was linked to an up-regulation in the expression of key antimicrobial peptides.

- Together, our results reveal the intricate relationship between macronutrient intake and resistance to infection, and integrate the molecular cross-talk between metabolic and immune pathways into the framework of nutritional immunology. 


\section{Introduction}

44 Infection and nutrition are intricately and intimately linked (Kelley and Bendich, 1996; Sheldon and Verhulst, 1996; Samartin and Chandra, 2000; Rolff and Siva-Jothy, 2003; CunninghamRundles et al., 2005; Bauer et al., 2006; Calder, 2006; Falagas and Kompoti, 2006; Amar et al., 2007; Klasing, 2007; Wu et al., 2007; Ayres and Schneider, 2009; Falagas et al., 2009; Lazzaro and Little, 2009; Sorci and Faivre, 2009; Hawley and Altizer, 2010; Ponton et al., 2011a; SchmidHempel, 2011; Huttunen and Syrjanen, 2013; Ponton et al., 2013; Genoni et al., 2014; Martinez et al., 2014, Vogelweith et al. 2015,). Recent studies have allowed a detailed molecular understanding of the cross-regulation between nutrition and immunity, with nutrient sensing pathways being identified as important regulators of innate immunity (Becker et al., 2010; Martin et al., 2012; Varma et al., 2014). Immunity can be activated independently to an infection and this regulation can act under conditions of fluctuating nutrient availability. While the underlying mechanisms are far from being fully understood, the relationship between diet, diet-induced metabolic diseases and

56 infections is clearly multi-factorial, with impairments of immune function playing a key role

57 (Martí et al., 2001; Nave et al., 2011). Better understanding the nutritional components that 58 influence immunity and resistance to infection is an important challenge with implications for animal and human health.

There is an ongoing debate on the effects of diet on immune responses to infections. Food

61 deprivation, and/or protein shortage has been reported to negatively affect immunity responses and survival after infection (Siva-Jothy and Thompson, 2002; Pletcher, Macdonald, Marguerie et al., 2002, Brunner et al., 2014) with infected hosts selecting a protein-biased diet that provided them with a better survival after infection (Lee et al., 2006; Povey et al., 2009; Povey et al., 2014). In 
infection (i.e., "resistance"), it provided the host with the ability to reduce the damage of the

67 infection on its health, also called "tolerance" (Ayres and Schneider, 2009, 2012). More recently, it has been shown that yeast restriction affects tolerance specifically to one strain of bacterium in a time-dependent manner; however, no effect on resistance was detected (Kutzer and Armitage, 2016, see also Miller and Cotter, 2017 and Howick and Lazzaro, 2014). have been revealed (Graham et al., 2014; Kay et al., 2014; Mason et al., 2014) with, for instance,

74 following infection with the gut pathogen Vibrio cholarae (Galenza et al., 2016). Although there is a clear effect of diet composition on resistance to infection and immune state, dietary manipulations have usually focused on changing single nutrients or varying the caloric content and nutrient ratio simultaneously, which hinders the ability to specifically measure the effects of food components and/or caloric content on immunity [but see (Cotter et al., 2011)]. There is now evidence that considering the interactive effects of nutrients is essential and offers a more ecologically relevant understanding (Cotter et al., 2011; Simpson and Raubenheimer, 2012;

81 Simpson et al., 2015).

Here, we explored the nutritional responses of Drosophila melanogaster after bacterial challenge and the consequences of such responses for survival following infection. We performed

84 a detailed investigation of the dietary modulation of constitutive innate immune gene expression

85 in an age-dependent manner. The effects of nutrition were measured through a geometric manipulation of the dietary protein and carbohydrate balance. Our observations unveiled

87 nutritional regulations of innate immune gene expression and resistance to bacterial infections, and 88 link these findings to nutritional self-medication. 


\section{Results}

\section{Bacterial infection induces a shift in dietary choice to a low P:C diet}

92 We first hypothesized that infection through septic injury with the pathogen Micrococcus luteus would modulate the nutritional selection of Drosophila melanogaster. Adult flies were offered a choice between two capillaries filled with either a sucrose or a yeast solution, and food intake was measured every two days for six days (Ja et al., 2007) (see Methods). While non-, sham- and $M$. luteus-infected flies ingested similar quantities of carbohydrate (cumulative consumption of carbohydrate over six days, One-way ANOVA, $F_{2,36}=1.775, p=0.185$, Supplementary Table 1), the consumption of protein was significantly different between the treatments (i.e., cumulative consumption of protein for six days, One way ANOVA, $F_{2,36}=5.853, p=0.007$, Supplementary

Table 1). Protein consumption was the lowest for flies infected with $M$. luteus and was the greatest for sham-infected and non-infected flies (Fig. 1). This reduction in protein intake by infected flies resulted in a marked change in the ingested dietary $\mathrm{P}: \mathrm{C}$ ratio, such that flies infected with $M$. luteus balanced their diet to a P:C ratio close to 1:9.6 (i.e., 9\% protein, Fig. 1) and non- and sham-infected to a P:C ratio of 1:3.8 (i.e., 20\% protein) and 1:3.2 (i.e., 25\% protein), respectively (Fig. 1).

106 six hours post-challenge (see Methods). Infection with M. luteus induced the greatest changes in 107 immune gene expression (Fig. 2). Relative to naïve flies, infection by M. luteus triggered the 108 enhanced expression of all of the antimicrobial peptides assayed (i.e., AttaA, CecA, CecC, DipB, Def, Mtk, Supplementary Table 2), as well as molecules involved in the transduction of the immune signal (i.e., spz and Dif, Supplementary Table 2). However, no significant effect of 
111 infection was detected on the level of expression of the two receptors involved in the recognition

112 of pathogens that we assayed (i.e., GNBP2 and PGRPSA, Supplementary Table 2 and Fig. 2).

113 Even though the expression levels of spz, CecA, CecC and DiptB were significantly greater in

114 sham-infected flies compared to non-infected insects, levels of expression of these genes remained

115 more elevated in infected individuals compared to sham-infected and non-infected individuals

116 (Fig. 2).

These first results show that when flies are infected with M. luteus, they shift their nutritional choice to a carbohydrate-biased (lower P:C) diet, which is above and beyond the stress of physical injury (i.e. compare sham-infected vs. infected).

\section{A low P:C diet can improve survival post-infection}

We then hypothesized that the shift to a low P:C diet observed for infected flies had survival significance. In this second experiment, non-, sham- and M. luteus-infected flies were fed one of three diets (high, medium and low P:C in a no-choice experiment) and survival was followed. As survival rate of flies (Cox regression, Treatment $X$ Diet: $\chi^{2}=26.97, \mathrm{df}=4, \mathrm{p}<0.001$, Treatment:

$127 \chi^{2}=66.28, \mathrm{df}=2, \mathrm{p}<0.001$, Diet: $\left.\chi^{2}=606.57, \mathrm{df}=2, \mathrm{p}<0.001\right)$. Survival was reduced on higher P:C 128 diets for the three groups of flies compared to the two other diets (Fig. 3). However, while naïve 129 flies survived in similar proportions on medium and low P:C diets (i.e., 24\% and 4\% protein) (Log 130 Rank pairwise comparisons, $\mathrm{p}>0.05$, Fig. 3A), M. luteus- and sham-infected flies survived 131 significantly better on the low P:C diet (i.e., 4\% protein) compared to the medium P:C diet (i.e., $13224 \%$ protein diet) (Log Rank pairwise comparisons, $\mathrm{p} \leq 0.05$; Fig. 3B\&C). At day 15, the interaction 
133 between diet and treatment significantly influence the percentage of dead flies (Supplementary

134 Table 3A). Flies on high P:C diet had great percentage of death (Supplementary Table 3B; post

135 hoc $\mathrm{p}>0.05)$. On medium P:C diet, we found a greater percentage of dead flies for flies infected

136 with M. luteus compared to sham-infected and naïve treatments (Supplementary Table 3A; post

137 hoc test, $\mathrm{p} \leq 0.05)$. Percentage of dead flies was also greater for sham-infected flies compared to

138 naïve individuals. On low P:C diet, however, the percentage of dead flies was not significantly

139 different between the 3 treatments (Supplementary Table 3A; post hoc test, $\mathrm{p}>0.05$ ).

These results suggest that flies better resisted infection by M. luteus when fed a low-

141 protein, high-carbohydrate diet.

\section{The P:C ratio influences the constitutive expression of antimicrobials}

144 We next investigated the underlying mechanisms mediating the effect of carbohydrate-biased diet

145 on immune state. Given our findings, we hypothesized that a low-protein, high-carbohydrate diet

146 stimulates the expression of immune genes. We measured the expression of 21 genes involved in

147 the integrated response to pathogen infection, beginning with pathogen recognition receptors,

148 transduction of the immune signals, and antimicrobial peptides (AMPs) for flies fed seven

149 isocaloric diets varying in the $\mathrm{P}: \mathrm{C}$ ratio (the percentage of dietary protein was used as a descriptor

150 in the analyses and figures, see Methods and Supplementary Table 4). Flies were sampled at three

151 key points on their life expectancy curves (i.e., 25, 50, 75\% mortality, see Supplementary Fig. 1

152 and Supplementary Table 5).

153 Our data show that immune genes expression levels were significantly influenced by the

154 ratio of protein-to-carbohydrate in the diet (expression data pooled for all AMPs; Kruskal-Wallis 
155

156

157

158

159

160

161

162

163

164

165

166

167

168

169

170

171

172

173

174

175

176

test: $25 \%$ mortality, $\chi^{2}=43.619, \mathrm{df}=6, \mathrm{p} \leq 0.001, \mathrm{~N}=157 ; 50 \%$ mortality, $\chi^{2}=27.279, \mathrm{df}=6, \mathrm{p} \leq 0.001$, $\mathrm{N}=158 ; 75 \%$ mortality, $\chi^{2}=51.345, \mathrm{df}=6, \mathrm{p} \leq 0.001, \mathrm{~N}=153$; Fig. 4). Expression level of the genes coding for AMPs was overall negatively associated with dietary P:C and this was observed at the three sampling times, though there is some suggestion of non-linear trends in the earlier sampling points. Expression of genes coding for immune receptors was significantly influenced by dietary P:C, however we did not detect any clear pattern of variation (Supplementary Fig. 2 and Supplementary Table 6). Diet composition did not influence expression levels of genes coding for molecules involved in the transduction of the immune signal (Supplementary Table 6).

When we looked in more details at the effect of dietary P:C on the expression level of the specific genes, we found a significant negative non-linear relationship between the level of expression and the percentage of dietary protein for six out of nine genes coding for antimicrobial peptides (Fig. 5), which reveals that antimicrobial peptide expression is tightly linked with the macronutrient balance in the diet. This diet-dependent effect on antimicrobial peptide expression was consistent throughout the flies' lifespan (see Supplementary Fig. 3).

Interestingly, we found that the effect of dietary P:C can vary depending on the sampling point and the specific gene. For example, for the pattern recognition proteins, gene expression was positively associated with P:C for PGRPSC2, GNBP1 (at 25\% mortality only for both genes) and PGRPLC (at 50\% mortality only), whereas there was a negative association for PGRPSA (at 25\% and 75\% mortality) and PGRPSB1 (at all sampling points) (see Supplementary Fig. 3). Expression of genes coding for proteins involved in the immune-signal transduction (i.e., Dif, Imd, Relish, Thor, Toll, Spätzle) was generally not significantly influenced by dietary P:C (Supplementary Fig. 3). Together, these results suggest that a carbohydrate-biased diet can maintain a higher 
177 constitutive expression of antimicrobial peptides that might allow flies to better fight infections 178 and injuries.

\section{Discussion}

181 Our results confirm the key role of protein and carbohydrate in immunity and resistance to 182 infection. Although the dietary ratio of protein to carbohydrate (P:C) modulated expression of genes linked to innate immunity, it did not affect all immune molecules in the same way (see also (Cotter et al., 2011)). While AMP expression levels were overall negatively affected by the relative amount of protein in the diet, the effects of dietary $\mathrm{P}: \mathrm{C}$ on molecules involved in the recognition on molecules involved in the transduction of the immune signal. individuals. While anorexia - i.e. a sharply decreased overall food intake - has been proposed to enhance tolerance and/or resistance [see for instance (Ayres and Schneider, 2009; Adamo et al., 2010)], our results strongly support the notion that modulation of macronutrient balance, rather than overall calories, may underpin this effect (Cotter et al., 2011) [see also (Fontana and Partridge, 2015) for a similar discussion on the effects of nutrients on longevity]. Furthermore, while shaminfected individuals survived better on low P:C, we did not observe any significant shift in their diet choice. The magnitude of the nutritional effects in sham-infected flies was a bit smaller compared to infected flies and might explain these results. More investigations are needed to fully understand this result. 

inhibiting the TOR pathway using mutants and the drug rapamycin results in an enhanced expression of several AMPs in Drosophila (Varma et al., 2014). Interestingly, this system can be manipulated by pathogens that have evolved ways to maintain TOR complex activity in an amino

209 acid-independent manner (Clippinger et al., 2011). Dietary protein to carbohydrate ratio was predicted to modulate TOR activation, as shown recently in mice (Simpson and Raubenheimer, 2009). As a result, we predict that antimicrobial peptides are up-regulated on high-carbohydrate, low-protein diets because of low TOR activation [see also (Varma et al., 2014)]. However, we did not detect a prophylactic effect of carbohydrate per se, as it has been suggested in an earlier study

214 (Galenza et al., 2016).

Micronutrients are also important food components that can modulate immunity (Calder,

2162017 for more details). We here approached foods as mixtures of macronutrients (and correlated

217 content of micronutrients) and do not specifically address the effects of micronutrients on fly 218 immunity. More investigations through specific manipulations of dietary micronutrient content 219 would allow to further explore the role of micronutrients on immunity and resistance to infection 220 in drosophila. 

with antiparasitic activity (Raubenheimer and Simpson, 2009; de Roode et al., 2013). However, selection to stimulate the immune response and potentially compensate for the negative effects of

227 the infection on fitness traits [see for instance (Abbott, 2014; Povey et al., 2014; Galenza et al., 2016; Bashir-Tanoli et al. 2014)]. Specific appetites for protein and carbohydrate mediate diet selection and food intake (Simpson et al., 2015) and better understanding the links and relationships between macronutrients, the immune state, and resistance to infection will inform the use of nutritional interventions as tools for improving the health of animal and human populations.

\section{Material and methods}

\section{Experimental infection}

235 One day-old adult female flies (Canton-S, stock from Bloomington) were experimentally infected

237 anaesthetized under $\mathrm{CO}_{2}$ and pricked in the thorax using a dissecting pin that was beforehand 238 dipped in the bacterial solution [see (Apidianakis and Rahme, 2009)]. We also generated sham239 infected flies using a pin dipped in ethanol (70\%). As negative controls, we used non-infected, 240 non-injured flies (i.e., naïve flies). Flies were left to recover from pricking for half an hour.

241 Survival immediately after the infection was $\sim 95 \%$. 


\section{Nutritional intake target}

244 Infected, sham-infected, and naïve flies were individually provided with two $5 \mu 1$ microcapillary tubes (Drummond Microcaps) filled with liquid diets ( $n=20$ flies per treatment at the start of the experiment): one diet consisted of autolyzed yeast (MP Biomedicals, catalogue no. 103304) at $180 \mathrm{~g} / \mathrm{L}$ and the other, of sucrose at $180 \mathrm{~g} / \mathrm{L}$. The two solutions were prepared in sterile, distilled water. Intake was measured against a scale bar by height difference in the column of liquid within the microcapillary every 2 days for 6 days [see (Lee et al., 2008; Ponton et al., 2015)]. Total quantities of protein and carbohydrate ingested were compared using One-way ANOVA type II and post-hoc tests (Tukey's HSD).

\section{Immune gene expression levels using RT-qPCR}

254 We investigated the expression of immune genes of the IMD and Toll pathways using reverse transcription quantitative PCR (RT-qPCR). We used 1d-old adult female infected, sham-infected, or control. After pricking, flies were left to recover for half an hour before being transferred to

257 P:C $=1: 4$ (3 replicate cages per treatment). After $6 \mathrm{~h}$, flies were dissected (i.e., eggs removed), preserved in RNA later (Ambion) and stored at $-80^{\circ} \mathrm{C}$. RNA was extracted for 10 to 15 flies per

259 cage (see below for more details on RNA extraction). Complementary DNA was generated using 260 the QuantiTect Reverse Transcription Kit (Qiagen). Triplicate cDNA aliquots for each sample 261 served as templates for quantitative PCR using SYBR Green PCR Master Mix (Applied 262 Biosystems). Amplification reactions were performed in $10 \mu 1$ total volumes with $4.5 \mu 1$ of cDNA 263 (diluted 1:90) and 100 to $200 \mathrm{nM}$ of each primer [see (Ponton et al., 2011b) for the primer 264 sequences of reference genes Rpl32 (Ribosomal protein 132, CG7939) and Ef1 (Elongation factor 
optical plates under the following sequential conditions: incubation at $50^{\circ} \mathrm{C}$ for $2 \mathrm{~min}, 95^{\circ} \mathrm{C}$ for 10 min, followed by 45 cycles of $95^{\circ} \mathrm{C}$ for $15 \mathrm{~s}$ and $60^{\circ} \mathrm{C}$ for 1 min. RT-qPCR efficiency was determined for each gene and each treatment using second derivative method. Relative standard curves for the gene transcripts were generated with serial (5x) dilutions of cDNA (i.e. 1/20, 1/40, $1 / 80,1 / 160$ and 1/320). Stock cDNA used for the relative standard curves consisted of a pool of cDNA from the different samples. No template and no RT controls were run for each primer pair. Target gene expression levels were normalized by reference gene expression levels. Expression levels were given relative to the control treatment (i.e., non-injured, non-infected flies) for each gene and compared between treatments using generalized linear model analysis (GLM) followed by post-hoc tests (Tukey's HSD). Effect of the percentage of dietary protein on each single gene expression level was analyzed using generalized additive model analysis (GAM).

\section{Effect of dietary manipulation on resistance to infection}

One day-old adult female flies were infected as described above. Flies were left to recover for half an hour before being transferred to experimental cages, and split into groups of 50 individuals fed with three solid diets varying in the $\mathrm{P}: \mathrm{C}$ ratio. Foods varied in hydrolysed yeast $(\mathrm{Y})$ and sucrose (S) content. The Y:S concentration was 180g/1. Macronutrient compositions were calculated based on autolyzed yeast [MP Biomedicals, catalogue no. 103304 containing $62 \%$ protein]. Each diet contained $0.01 \%$ phosphoric acid and $0.1 \%$ proprionic acid as antimould agents and were prepared in sterile, distilled water. Dietary treatments were defined as "high P:C ratio" (i.e., P:C=1:1 or 52\% P), "medium P:C ratio" (i.e., $\mathrm{P}: \mathrm{C}=1: 4$ or $24 \% \mathrm{P}$ ) and "low P:C ratio" (i.e., $\mathrm{P}: \mathrm{C}=1: 32$ or $4 \% \mathrm{P}$ ).

Three replicates cages for M. luteus- and sham-infected flies and two replicate cages with naïve flies were run in parallel for each dietary treatment. Lifespan was followed for 16 days with dead 
flies counted daily. Flies that died from 0 to $6 \mathrm{~h}$ post-infection were removed from the analyses since we could not assess if the death was directly caused by the infection or the dietary treatment. Kaplan-Meier lifespan curves were analyzed using Cox regression and Log Rank Mantel-Cox tests.

\section{Immune gene expression levels using Taqman Low-Density Array (TLDA) cards}

Dietary treatments-Foods varied in hydrolysed yeast $(\mathrm{Y})$ and sucrose $(\mathrm{S})$ content. The seven $\mathrm{Y}: \mathrm{S}$ ratios used were $1: 14,1: 7,1: 3.5,1: 1.6,1: 0.7,1: 0.2$, or 1:0; yielding protein-to-carbohydrate ratios of $1: 21,1: 11,1: 5,1: 2.5,1: 1,3: 1$ and 1:0, respectively; and percentages of protein $(\mathrm{w} / \mathrm{w}(\mathrm{Y}+\mathrm{S}))$ of $4 \%, 8 \%, 14 \%, 24 \%, 36 \%, 52 \%$ and $62 \%$, respectively. The Y:S concentration was $180 \mathrm{~g} / 1$. Macronutrient compositions were calculated based on autolyzed yeast [MP Biomedicals, catalogue no. 103304 containing 62\% protein]. Each solid diet contained $0.01 \%$ phosphoric acid and $0.1 \%$ proprionic acid as antimould agents and were prepared in sterile, distilled water.

Fly sampling-Newly-eclosed female flies were sorted and placed in longevity cages. Three replicate cages were run per diet (i.e., P:C 1:21, 1:11, 1:5, 1:2.5, 1:1, 3:1 and 1:0), each with 180 flies. Dead individuals were counted and removed from the cages every two days until all flies were dead. Life expectancy curves were analyzed using Log Rank Mantel-Cox tests. Ten live flies per treatment cage were sampled at 25\%,50\% and 75\% mortality (see Supplementary Fig. 1 and Supplementary Table 4). Flies were dissected (i.e, eggs removed), preserved in RNA later (Ambion) and stored at $-80{ }^{\circ} \mathrm{C}$ for further analyses.

$\boldsymbol{R N A}$ extractions- We prepared up to three total RNA samples per dietary treatment by pooling individuals $(\mathrm{n}=10)$ of the same replicate cage. When less than 10 flies remained in the longevity cages, we discarded the sample. Subsequently, total RNA was extracted using a Trizol/RNeasy 
312 (Plus Mini kit, Qiagen) hybrid extraction protocol [see (Ponton et al., 2011b)]. Briefly, insects

313 were homogenised in $1 \mathrm{ml}$ TRIzol reagent using a TissueLyser and $7 \mathrm{~mm}$ stainless beads. Samples

314 were incubated for $15 \mathrm{~min}$ at room temperature and centrifuged for $10 \mathrm{~min}$ at $12,000 \times \mathrm{g}$ at $4{ }^{\circ} \mathrm{C}$. A

315 standard volume of supernatant $(800 \mu \mathrm{l})$ was removed and added to $200 \mu \mathrm{l}$ of chloroform. Tubes

316 were shaken vigorously for $15 \mathrm{~s}$, incubated at room temperature for $3 \mathrm{~min}$ and centrifuged for $20 \mathrm{~min}$

317 at $12,000 \times \mathrm{g}$ at $4^{\circ} \mathrm{C}$. The aqueous phase $(350 \mu \mathrm{l})$ was transferred to a gDNA eliminator column

318 from an RNeasy Plus Mini Kit (Qiagen) and all other steps were performed according to the

319 manufacturer's protocol (i.e. from step 4 in the version from Oct. 2005). Total RNA was eluted in

$32035 \mu \mathrm{l}$ of water. Extraction was followed by a DNase treatment (Ambion) to eliminate potential

321 genomic DNA in the samples. RNA was then stored at $-80^{\circ} \mathrm{C}$ before further processing. The

322 quality and quantity of RNA was assessed with a Nanodrop ND-1000 spectrophotometer

323 (Nanodrop Technologies). cDNA was produced using the QuantiTect Reverse Transcription Kit

324 (Qiagen). cDNA was stored at $-20^{\circ} \mathrm{C}$ until used.

325 Gene expression analysis- Gene expression was evaluated using custom made Taqman Low-

326 Density Array (TLDA) Cards (Life Technologies/Applied Biosystems). Each TLDA card allowed

327 for eight samples and assayed the expression of 21 immune genes (see Supplementary Table 4).

328 Target gene expression levels were normalized using four reference genes (i.e., Ef1 $\alpha 100 \mathrm{E}$,

$329 \alpha$ Tub84B, RpL32 and 18SrNA, see Supplementary Table 3). All samples were run on an ABI

330 model 7900HT sequence detection system according to the protocol supplied by the manufacturer.

331 Results were summarized using the $2^{-\Delta \Delta \mathrm{Ct}}$ method. We log transformed the response variable

332 before making statistical inferences, although all plots are of the raw data.

The effect of the percentage of dietary P:C was then tested for each gene and time point

individually using generalized additive models (GAMs) that allowed for no a priori decision for 
335 choosing a particular response function. The percentage of protein in the diet was used as a 336 descriptor of the diet composition.

\section{Statistical analyses}

339 Statistical analyses were run using R (R Development Core Team, 2013) and SPSS (IBM Corp.

340 released 2012. IBM SPSS Statistics for WINDOWS, v. 21.0. Armonk, NY: IBM Corp.).

342 Author Contributions

343 FP and SJS designed the experiments. FP, KR and SSK ran the experiments. FP and JM analyzed

344 the results. FP, JM, KR, SC, SSK, KW and SJS wrote the manuscript.

\section{Acknowledgments}

347 The study was funded by the Australian Research Council (DP130103222 to SJS, KW and FP)

348 and Macquarie University Research Seeding Grants (ID: 38277130 to FP). 


\section{References}

Abbott, J., 2014. Self-medication in insects: current evidence and future perspectives. Ecological Entomology 39, 273-280.

Abdel-Nour, M., Tsalikis, J., Kleinman, D., Girardin, S.E., 2014. The emerging role of mTOR signalling in antibacterial immunity. Immunol Cell Biol 92, 346-353.

Adamo, S.A., Bartlett, A., Le, J., Spencer, N., Sullivan, K., 2010. Illness-induced anorexia may reduce trade-offs between digestion and immune function. Animal Behaviour 79, 3-10.

Amar, S., Zhou, Q., Shaik-Dasthagirisaheb, Y., Leeman, S., 2007. Diet-induced obesity in mice causes changes in immune responses and bone loss manifested by bacterial challenge. Proceedings of the National Academy of Sciences 104, 20466-20471.

Apidianakis, Y., Rahme, L.G., 2009. Drosophila melanogaster as a model host for studying Pseudomonas aeruginosa infection. Nature Protocols 4, 1285-1294.

Ayres, J.S., Schneider, D.S., 2009. The Role of Anorexia in Resistance and Tolerance to Infections in Drosophila. PLoS Biology 7, e1000150.

Ayres J.S., Schneider D.S. (2012) Tolerance of infections. Annual Review in Immunology, 30, 271-294.

Bashir-Tanoli, S., Tinsley, M.C., 2014. Immune response costs are associated with changes in resource acquisition and not resource reallocation. Functional ecology 28, 1011-1019.

Bauer, M., Katzenberger, J.D., Hamm, A.C., Bonaus, M., Zinke, I., Jaekel, J., Pankratz, M.J., 2006. Purine and folate metabolism as a potential target of sex-specific nutrient allocation in Drosophila and its implication for lifespan-reproduction tradeoff. Physiological Genomics 25, 393-404.

Becker, T., Loch, G., Beyer, M., Zinke, I., Aschenbrenner, A.C., Carrera, P., Inhester, T., Schultze, J.L., Hoch, M., 2010. FOXO-dependent regulation of innate immune homeostasis. Nature 463, 369-373.

Brunner, F.S., Schmid-Hempel, P., Barribeau, S.M., 2014. Protein-poor diet reduces host-specific immune gene expression in Bombus terrestris. Proceedings of the Royal Society B: Biological Sciences 281.

Calder, P.C., 2006. n-3 Polyunsaturated fatty acids, inflammation, and inflammatory diseases. The American Journal of Clinical Nutrition 83, S1505-1519S.

Chakrabarti, S., Liehl, P., Buchon, N., Lemaitre, B., 2012. Infection-Induced Host Translational Blockage Inhibits Immune Responses and Epithelial Renewal in the Drosophila Gut. Cell Host \& Microbe 12, 60-70.

Clippinger, A.J., Maguire, T.G., Alwine, J.C., 2011. Human Cytomegalovirus Infection Maintains mTOR Activity and Its Perinuclear Localization during Amino Acid Deprivation. Journal of Virology 85, 9369-9376.

Cotter, S.C., Simpson, S.J., Raubenheimer, D., Wilson, K., 2011. Macronutrient balance mediates trade-offs between immune function and life history traits. Functional Ecology 25, 186-198.

Cunningham-Rundles, S., McNeeley, D.F., Moon, A., 2005. Mechanisms of nutrient modulation of the immune response. Journal of Allergy and Clinical Immunology 115, 1119-1128.

de Roode, J.C., Lefevre, T., Hunter, M.D., 2013. Ecology. Self-medication in animals. Science 340, 150-151.

Falagas, M.E., Athanasoulia, A.P., Peppas, G., Karageorgopoulos, D.E., 2009. Effect of body mass index on the outcome of infections: a systematic review. Obesity Reviews 10, 280-289. 
Falagas, M.E., Kompoti, M., 2006. Obesity and infection. The Lancet Infectious Diseases 6, 438446.

Fontana, L., Partridge, L., 2015. Promoting Health and Longevity through Diet: From Model Organisms to Humans. Cell 161, 106-118.

Galenza, A., Hutchinson, J., Campbell, S.D., Hazes, B., Foley, E., 2016. Glucose modulates Drosophila longevity and immunity independent of the microbiota. Biology Open 5, 165-173.

Genoni, G., Prodam, F., Marolda, A., Giglione, E., Demarchi, I., Bellone, S., Bona, G., 2014. Obesity and infection: two sides of one coin. European journal of pediatrics 173, 25-32.

Graham, R.I., Deacutis, J.M., Pulpitel, T., Ponton, F., Simpson, S.J., Wilson, K., 2014. Locusts increase carbohydrate consumption to protect against a fungal biopesticide. Journal of Insect Physiology 69, 27-34.

Hawley, D.M., Altizer, S.M., 2010. Disease ecology meets ecological immunology: understanding the links between organismal immunity and infection dynamics in natural populations, Functional Ecology 25, 48-60.

Howick, V. M., Lazzaro, B. P.,2014. Genotype and diet shape resistance and tolerance across distinct phases of bacterial infection. BMC Evolutionary Biology 14, 56.

Huttunen, R., Syrjanen, J., 2013. Obesity and the risk and outcome of infection. International Journal of Obesity 37, 333-340.

Ja, W.W., Carvalho, G.B., Mak, E.M., de la Rosa, N.N., Fang, A.Y., Liong, J.C., Brummel, T., Benzer, S., 2007. Prandiology of Drosophila and the CAFE assay. Proceedings of the National Academy of Sciences 104, 8253-8256.

Kay, A.D., Bruning, A.J., van Alst, A., Abrahamson, T.T., Hughes, W.O.H., Kaspari, M., 2014. A carbohydrate-rich diet increases social immunity in ants. Proceedings of the Royal Society B: Biological Sciences 281, 20132374.

Kelley, D., Bendich, A., 1996. Essential nutrients and immunologic functions. The American Journal of Clinical Nutrition 63, 994S-996S.

Klasing, K.C., 2007. Nutrition and the immune system. British Poultry Science 48, 525-537.

Kutzer, M.A.M., Armitage, S.A.O., 2016. The effect of diet and time after bacterial infection on fecundity, resistance, and tolerance in Drosophila melanogaster. Ecology and Evolution 6, 4229-4242.

Lazzaro, B.P., Little, T.J., 2009. Immunity in a variable world. Philosophical Transactions of the Royal Society B-Biological Sciences 364, 15-26.

Lee, K.P., Cory, J.S., Wilson, K., Raubenheimer, D., Simpson, S.J., 2006. Flexible diet choice offsets protein costs of pathogen resistance in a caterpillar. Proc Biol Sci 273, 823-829.

Lee, K.P., Simpson, S.J., Clissold, F.J., Brooks, R., Ballard, J.W., Taylor, P.W., Soran, N., Raubenheimer, D., 2008. Lifespan and reproduction in Drosophila: New insights from nutritional geometry. Proceedings of the National Academy of Sciences of the United States of America 105, 2498-2503.

Martí, A., Marcos, A., Martínez, J.A., 2001. Obesity and immune function relationships. Obesity Reviews 2, 131-140.

Martin, S., Saha, B., Riley, J.L., 2012. The Battle over mTOR: An Emerging Theatre in HostPathogen Immunity. PLoS Pathogens 8, e1002894.

Martinez, J., Longdon, B., Bauer, S., Chan, Y.-S., Miller, W.J., Bourtzis, K., Teixeira, L., Jiggins, F.M., 2014. Symbionts Commonly Provide Broad Spectrum Resistance to Viruses in Insects: A Comparative Analysis of Wolbachia Strains. PLoS Pathogens 10, e1004369. 
Mason, A.P., Smilanich, A.M., Singer, M.S., 2014. Reduced consumption of protein-rich foods follows immune challenge in a polyphagous caterpillar. The Journal of Experimental Biology 217, 2250-2260.

Miller, C., Cotter, S., 2017. Resistance and tolerance: the role of nutrients on pathogen dynamics and infection outcomes in an insect host. Journal of Animal Ecology 87, 500-510.

Nave, H., Beutel, G., Kielstein, J.T., 2011. Obesity-related immunodeficiency in patients with pandemic influenza H1N1. The Lancet. Infectious diseases 11, 14-15.

Pletcher, S. D., Macdonald, S. J., Marguerie, R., Certa, U., Stearns, S. C., Goldstein, D. B. and Partridge, L., 2002. Genome-Wide Transcript Profiles in Aging and Calorically Restricted Drosophila melanogaster. Current Biology 12, 712-723.

Ponton, F., Wilson, K., Cotter, S.C., Raubenheimer, D., Simpson, S.J., 2011a. Nutritional immunology: a multi-dimensional approach. PLoS Pathogens 7, e1002223.

Ponton, F., Chapuis, M.P., Pernice, M., Sword, G.A., Simpson, S.J., 2011 b. Evaluation of potential reference genes for reverse transcription-qPCR studies of physiological responses in Drosophila melanogaster. Journal of Insect Physiology 57, 840-850.

Ponton, F., Wilson, K., Holmes, A., Raubenheimer, D., Robinson, K.L., Simpson, S.J., 2015. Macronutrients mediate the functional relationship between Drosophila and Wolbachia. Proceedings of the Royal Society of London B 282, 20142029.

Ponton, F., Wilson, K., Holmes, A.J., Cotter, S.C., Raubenheimer, D., Simpson, S.J., 2013. Integrating nutrition and immunology: A new frontier. Journal of Insect Physiology 59, 130137.

Povey, S., Cotter, S.C., Simpson, S.J., Lee, K.P., Wilson, K., 2009. Can the protein costs of bacterial resistance be offset by altered feeding behaviour? Journal of Animal Ecology 78, 437446.

Povey, S., Cotter, S.C., Simpson, S.J., Wilson, K., 2014. Dynamics of macronutrient selfmedication and illness-induced anorexia in virally infected insects. Journal of Animal Ecology 83, 245-255.

Raubenheimer, D., Simpson, S.J., 2009. Nutritional PharmEcology: Doses, nutrients, toxins, and medicines. Integrative and Comparative Biology 49, 329-337.

Rolff, J., Siva-Jothy, M.T., 2003. Invertebrate ecological immunology. Science 301, 472-475.

Samartin, S., Chandra, R.K., 2000. Obesity, overnutrition and the immune system. Nutrition Research 21, 243-262.

Schmid-Hempel, P., 2011. Evolutionary Parasitology, Oxford University Press, Oxford.

Seiler, F., Hellberg, J., Lepper, P.M., Kamyschnikow, A., Herr, C., Bischoff, M., Langer, F., Schäfers, H.-J., Lammert, F., Menger, M.D., Bals, R., Beisswenger, C., 2013. FOXO Transcription Factors Regulate Innate Immune Mechanisms in Respiratory Epithelial Cells. The Journal of Immunology 190, 1603-1613.

Sheldon, B.C., Verhulst, S., 1996. Ecological immunology: costly parasite defences and trade-offs in evolutionary ecology. Trends in Ecology \& Evolution 11, 317-321.

Simpson, S.J., Le Couteur, D.G., Raubenheimer, D., 2015. Putting the Balance Back in Diet. Cell $161,18-23$.

Simpson, S.J., Raubenheimer, D., 2009. Macronutrient balance and lifespan. Aging 1, 875-880.

Simpson, S.J., Raubenheimer, D., 2012. The Nature of Nutrition: a unifying framework from animal adaptation to human obesity. Princeton University Press, Princeton.

Siva-Jothy, M.T., Thompson, J.J.W., 2002. Short-term nutrient deprivation affects immune function. Physiological Entomology 27, 206-212. 
484 Sorci, G., Faivre, B., 2009. Inflammation and oxidative stress in vertebrate host-parasite systems. Philosophical Transactions of the Royal Society B: Biological Sciences 364, 71-83. Emili, A., Philpott, Dana J., Girardin, Stephen E., 2012. Amino Acid Starvation Induced by Invasive Bacterial Pathogens Triggers an Innate Host Defense Program. Cell Host \& Microbe 11, 563-575.

Varma, D., Bülow, M.H., Pesch, Y.-Y., Loch, G., Hoch, M., 2014. Forkhead, a new cross regulator of metabolism and innate immunity downstream of TOR in Drosophila. Journal of Insect Physiology 69, 80-88. in a phytophagous insect: An effect of nutrition rather than parasitic contamination. Journal of insect physiology 77, 55-61.

496 Wu, J., Randle, K.E., Wu, L.P., 2007. ird1 is a Vps15 homologue important for antibacterial immune responses in Drosophila. Cellular Microbiology 9, 1073-1085. 
Figure 1. Cumulative protein-carbohydrate intake (mean+s.e.m.) trajectories at two-day intervals over six days. Dotted lines represent protein-to-carbohydrate ratios $(\mathrm{P}: \mathrm{C})$. Letters indicate significant HSD Tukey's pairwise comparisons $(\mathrm{p} \leq 0.05)$.

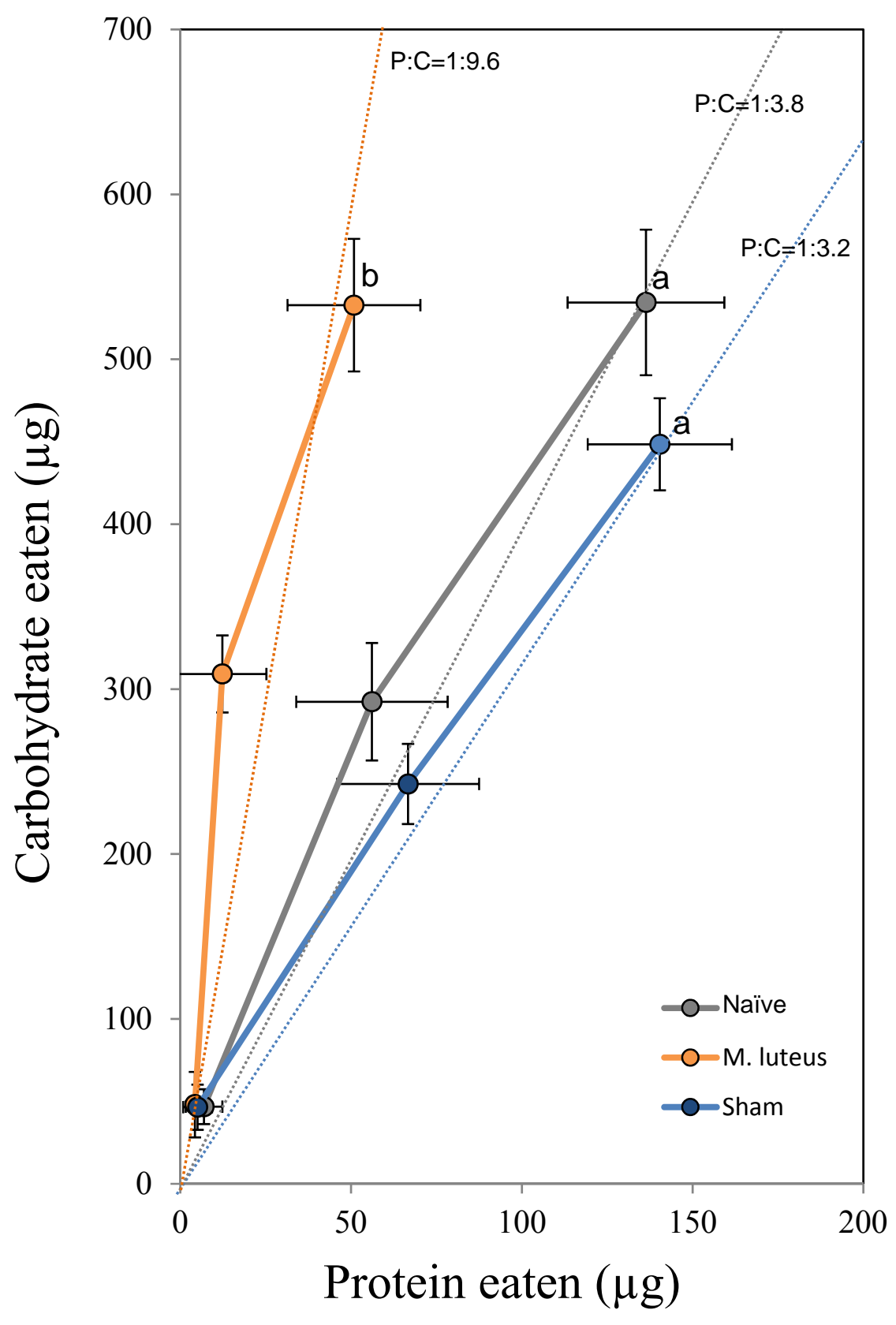


Figure 2. Relative immune gene expression (relative to naïve flies, mean+s.e.m.). Letters indicate significant HSD Tukey's pairwise comparisons $(\mathrm{p} \leq 0.05)$ between sham-injured and M. luteusinfected flies, stars $\left(^{*}\right)$ indicate significant Bonferroni pairwise comparisons $(\mathrm{p} \leq 0.05)$ against naïve flies.

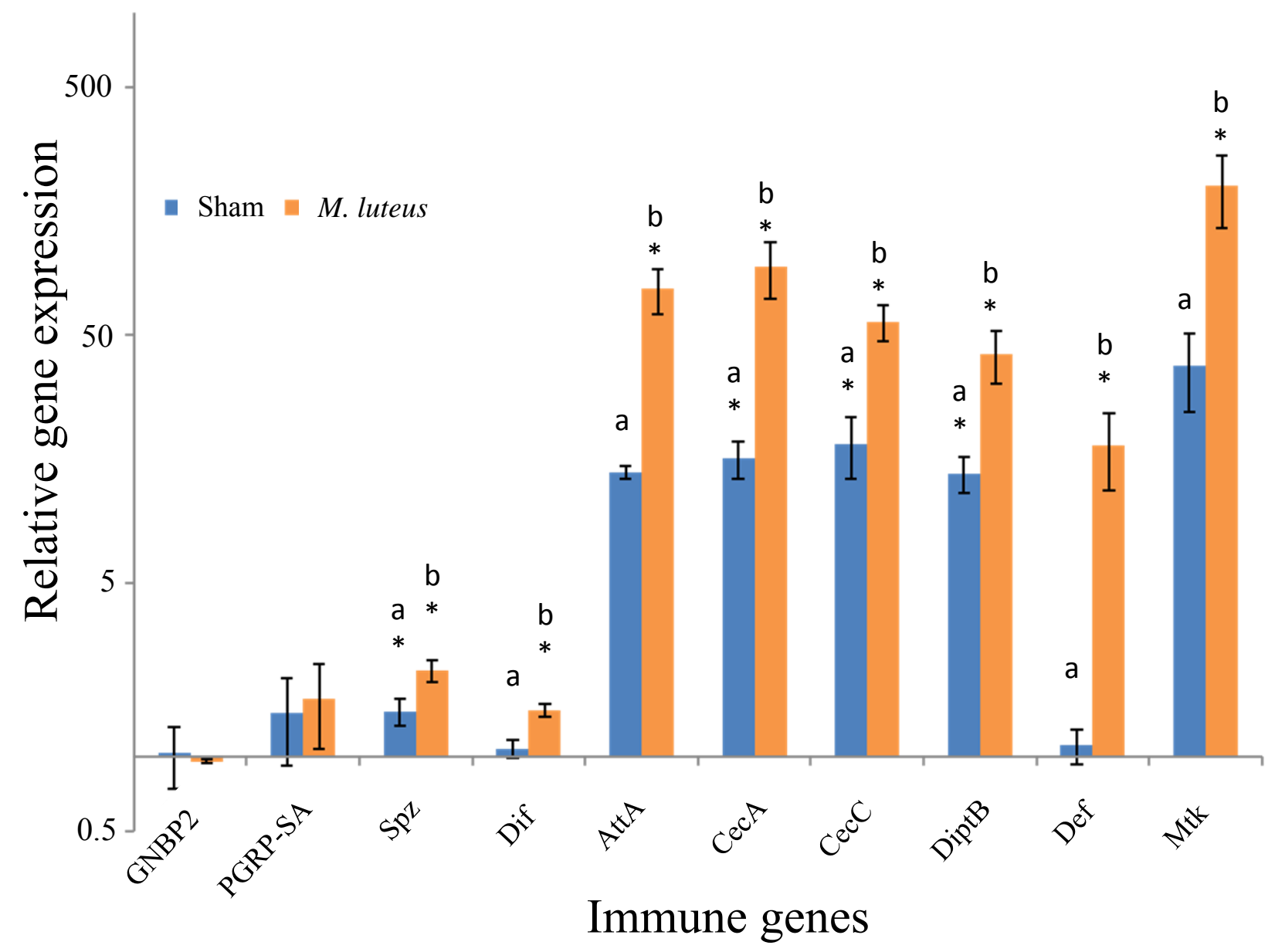


Figure 3. Survival curves of flies fed three diets varying in the protein-to-carbohydrate ratio (P:C) [i.e, P:C=1:1 (high), 1:4 (medium), and 1:32 (low)] after treatment (Naïve, Sham- and $M$. luteus-infected). Letters indicate significant pairwise comparisons $(\mathrm{p} \leq 0.05)$.
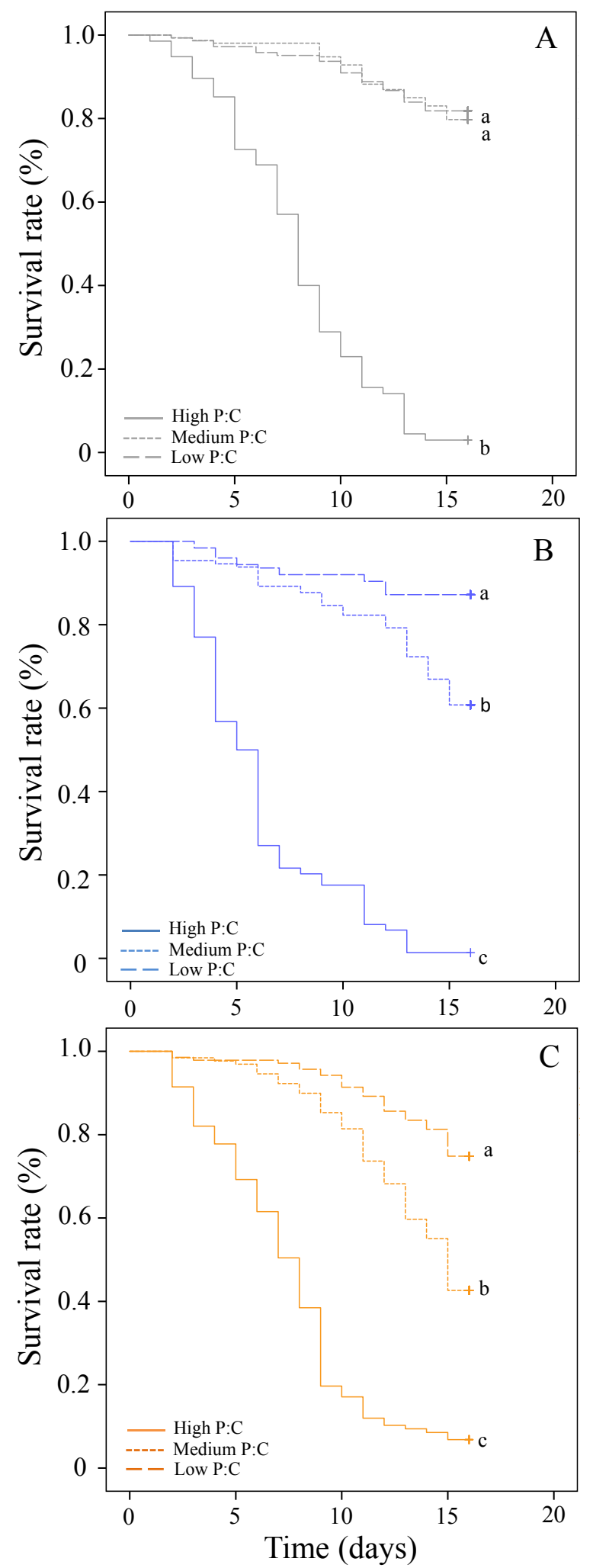
Figure 4. Expression levels of antimicrobial genes (mean $\pm \mathrm{SE}$ ) according to the percentage of protein in the diet at: A. 25\% mortality, B. 50\% mortality, C. $75 \%$ mortality.
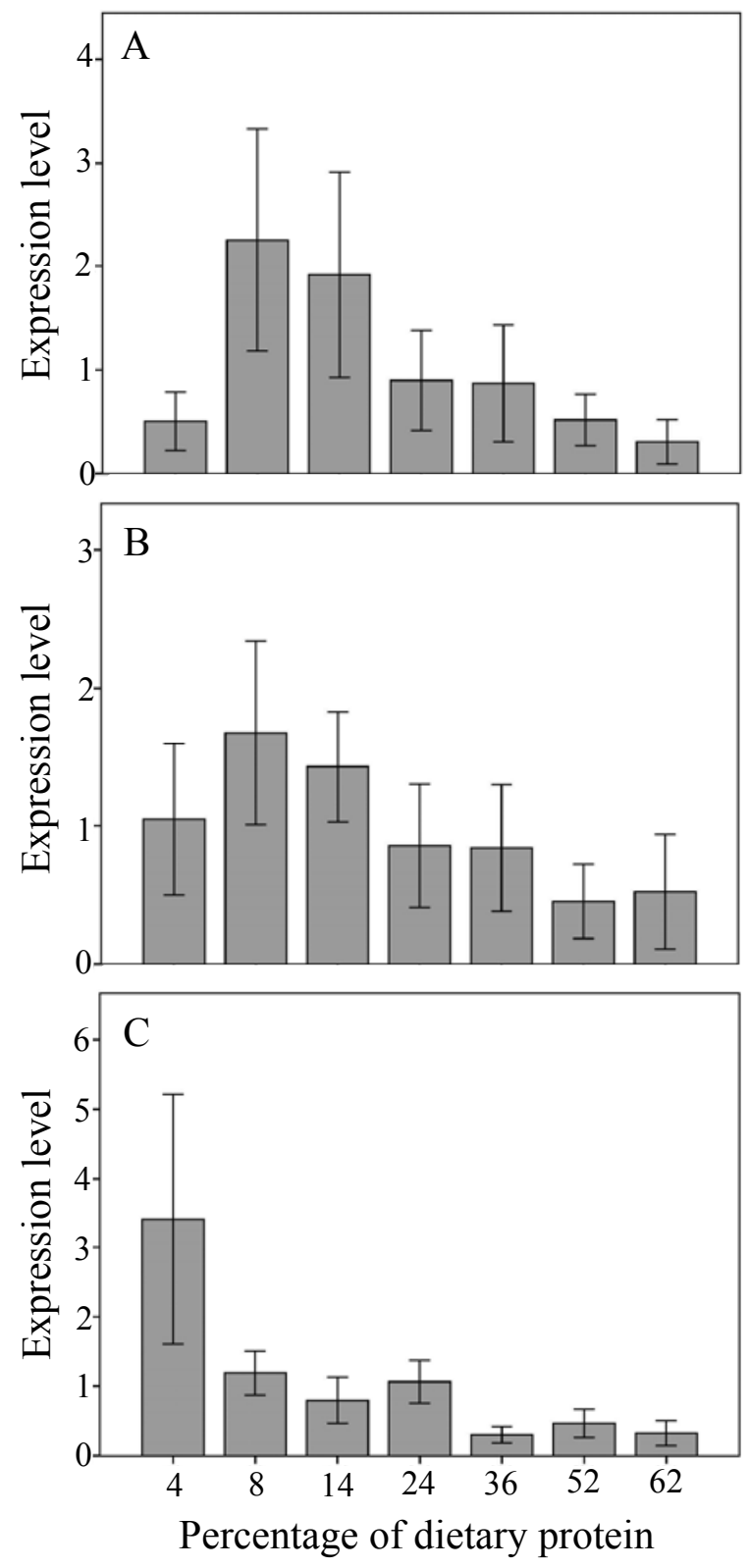
Figure 5. Estimated nonparametric smooths of antimicrobial gene expression levels from the generalized additive model according to the percentage of dietary protein at $50 \%$ survival (Def= defensin, DptB $=$ DiptericinB, AttC $=$ AttacinC, CecA1=CecropinA1, Mtk= Metchnikowin, AttD= AttacinD).
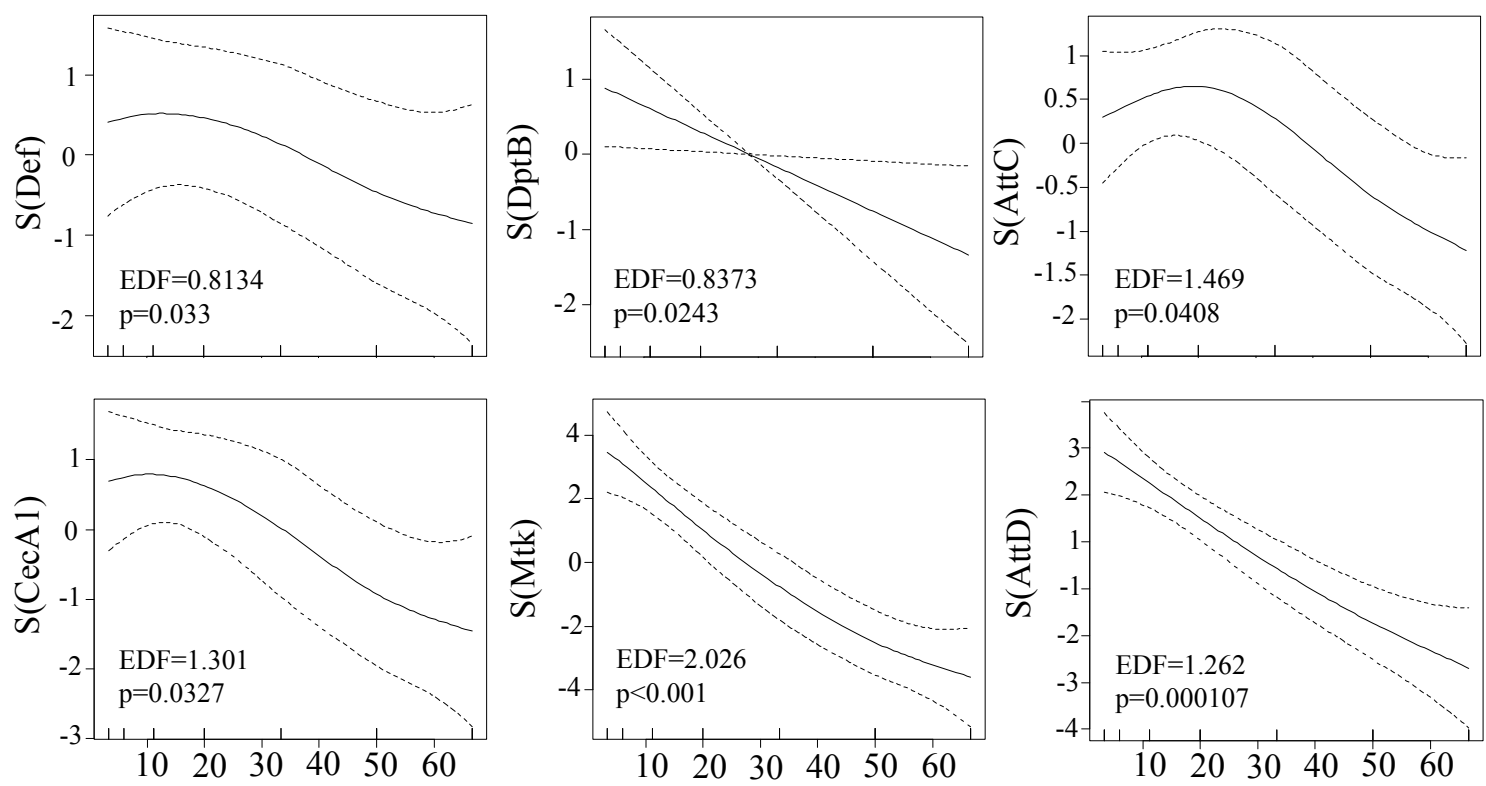

Percentage of dietary protein

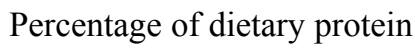

Percentage of dietary protein 
bioRxiv preprint doi: https://doi.org/10.1101/498493; this version posted December 17, 2018. The copyright holder for this preprint (which was not certified by peer review) is the author/funder, who has granted bioRxiv a license to display the preprint in perpetuity. It is made available under aCC-BY 4.0 International license.

Supplementary Figure 1. Life expectancy Kaplan-Meier curves with 95\% confidence for flies fed seven diets varying in the percentage of protein $(P)\left(\log\right.$ Rank test, $\left.\chi^{2}=3166.5, \mathrm{df}=6, \mathrm{p} \leq 0.001\right)$.

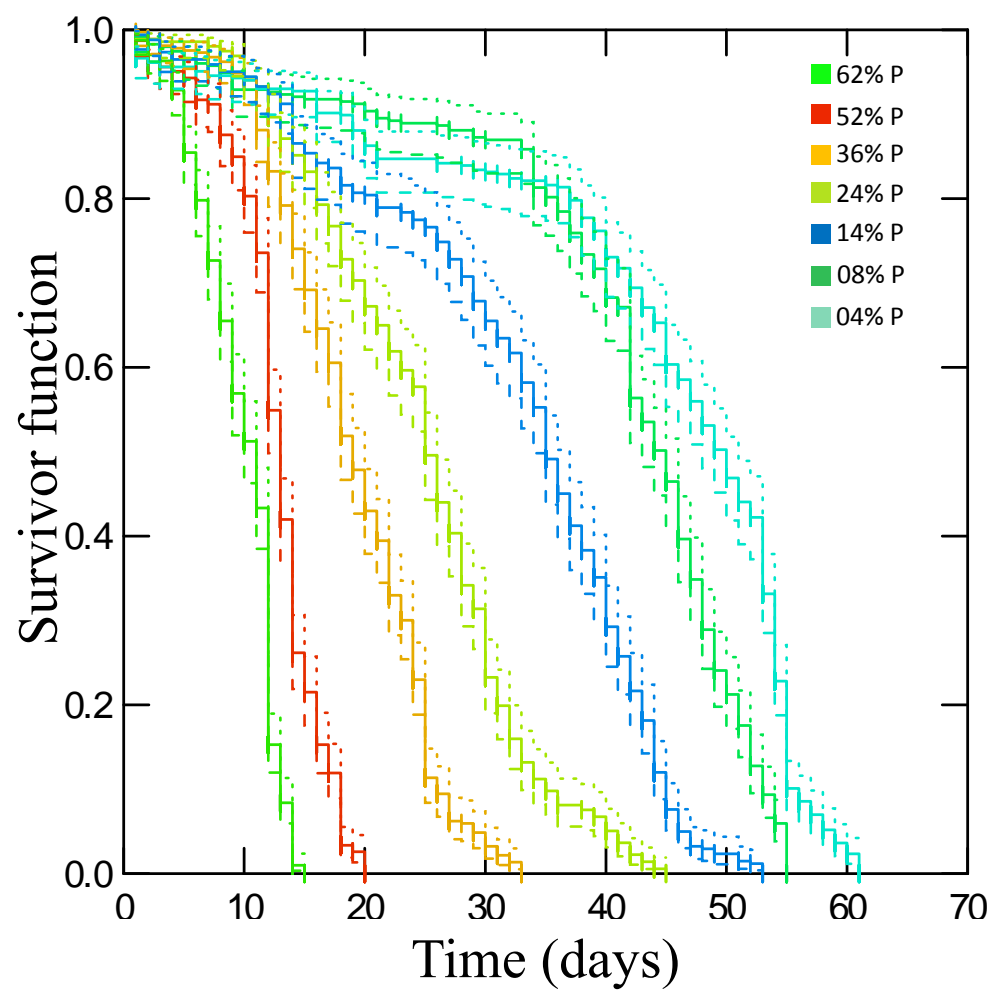


Supplementary Figure 2. Expression levels of immune receptors (mean $\pm \mathrm{SE}$ ) according to the percentage of protein in the diet at: A. 25\% mortality, B. 50\% mortality, C. $75 \%$ mortality.
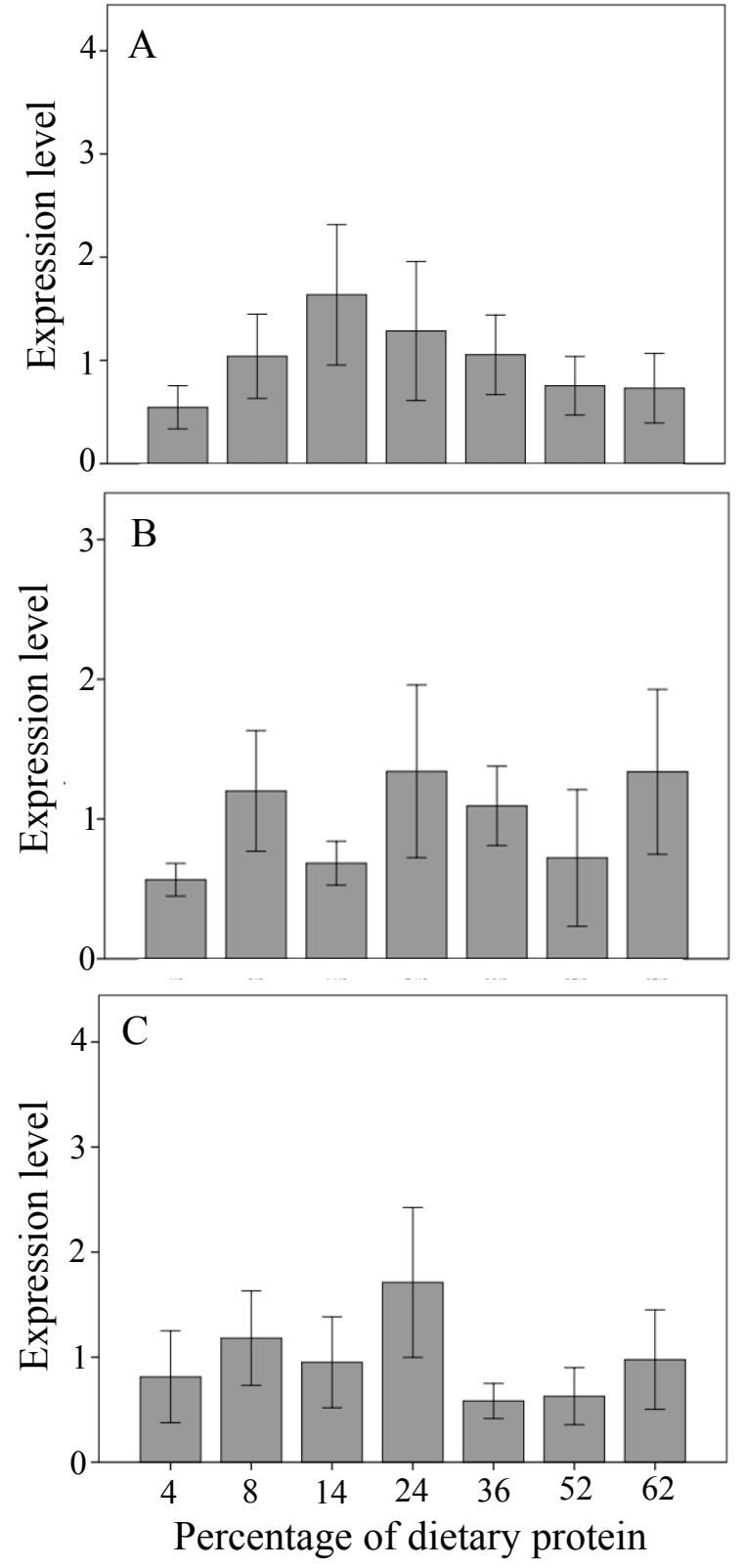
Supplementary Figure 3. Estimated nonparametric smooths of immune gene expression levels from the generalized additive model according to the percentage of dietary protein at $25 \%, 50 \%$ and $75 \%$ mortality. 
bioRxiv preprint doi: https://doi.org/10.1101/498493; this version posted December 17, 2018. The copyright holder for this preprint (which was not certified by peer review) is the author/funder, who has granted bioRxiv a license to display the preprint in perpetuity. It is made available under aCC-BY 4.0 International license.

Supplementary Figure 3 (1/4) Molecules involved in the recognition of pathogens
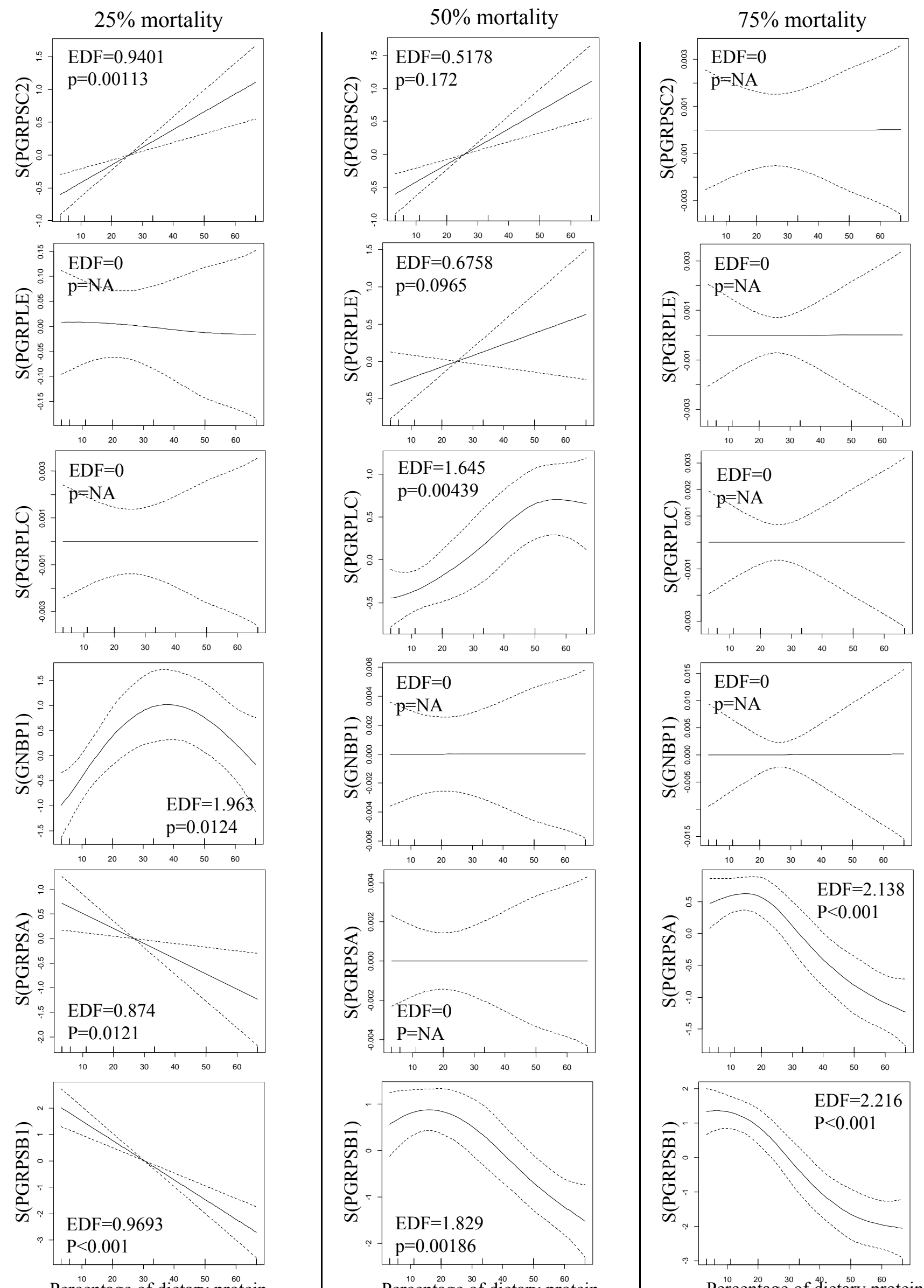

Percentage of dietary protein

Percentage ${ }^{10}{ }^{30}$ dietary $^{50}$ protein $^{60}$

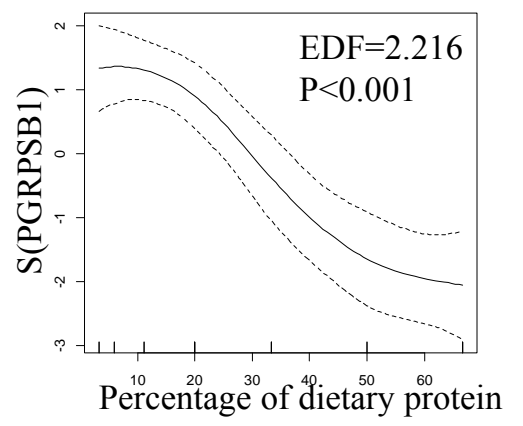


bioRxiv preprint doi: https://doi.org/10.1101/498493; this version posted December 17, 2018. The copyright holder for this preprint (which was not certified by peer review) is the author/funder, who has granted bioRxiv a license to display the preprint in perpetuity. It is made available under aCC-BY 4.0 International license.

Supplementary Figure 3 (2/4) Molecules involved in the transduction of the immune signal $25 \%$ mortality
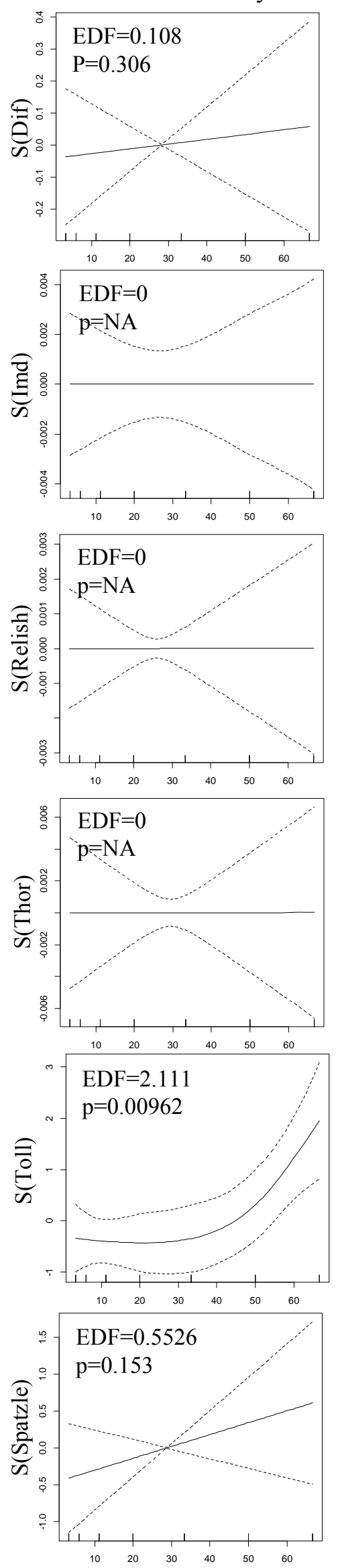

Percentage of dietary protein $50 \%$ mortality
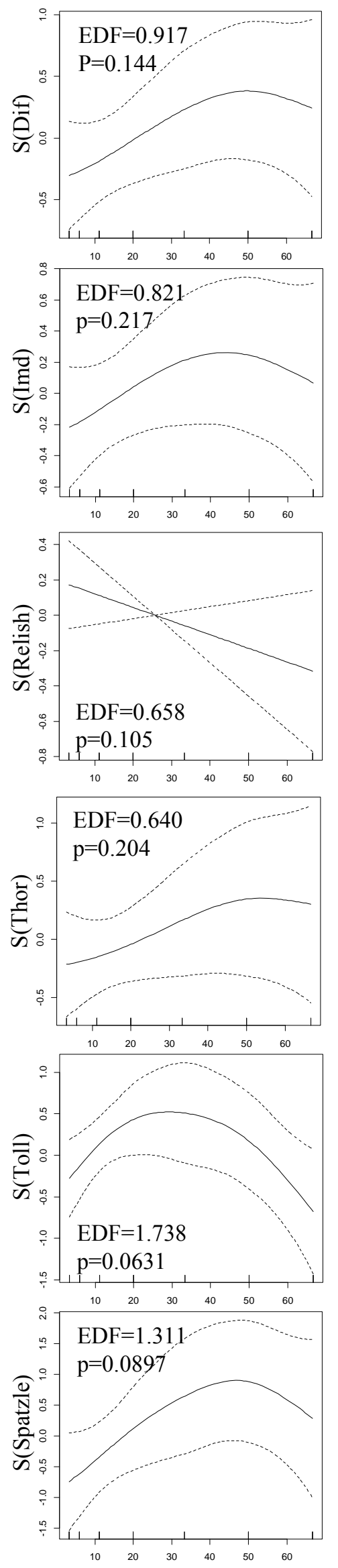

Percentage of dietary protein
$75 \%$ mortality
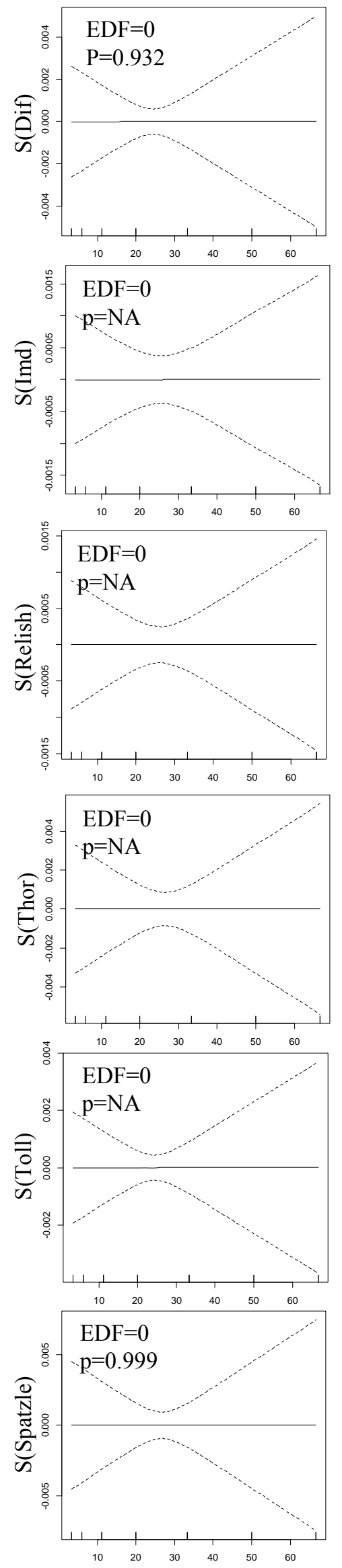

Percentage of dietary protein 
bioRxiv preprint doi: https://doi.org/10.1101/498493; this version posted December 17, 2018. The copyright holder for this preprint (which was not certified by peer review) is the author/funder, who has granted bioRxiv a license to display the preprint in perpetuity. It is made available under aCC-BY 4.0 International license.

\section{Supplementary Figure 3 (3/4) Antimicrobials}
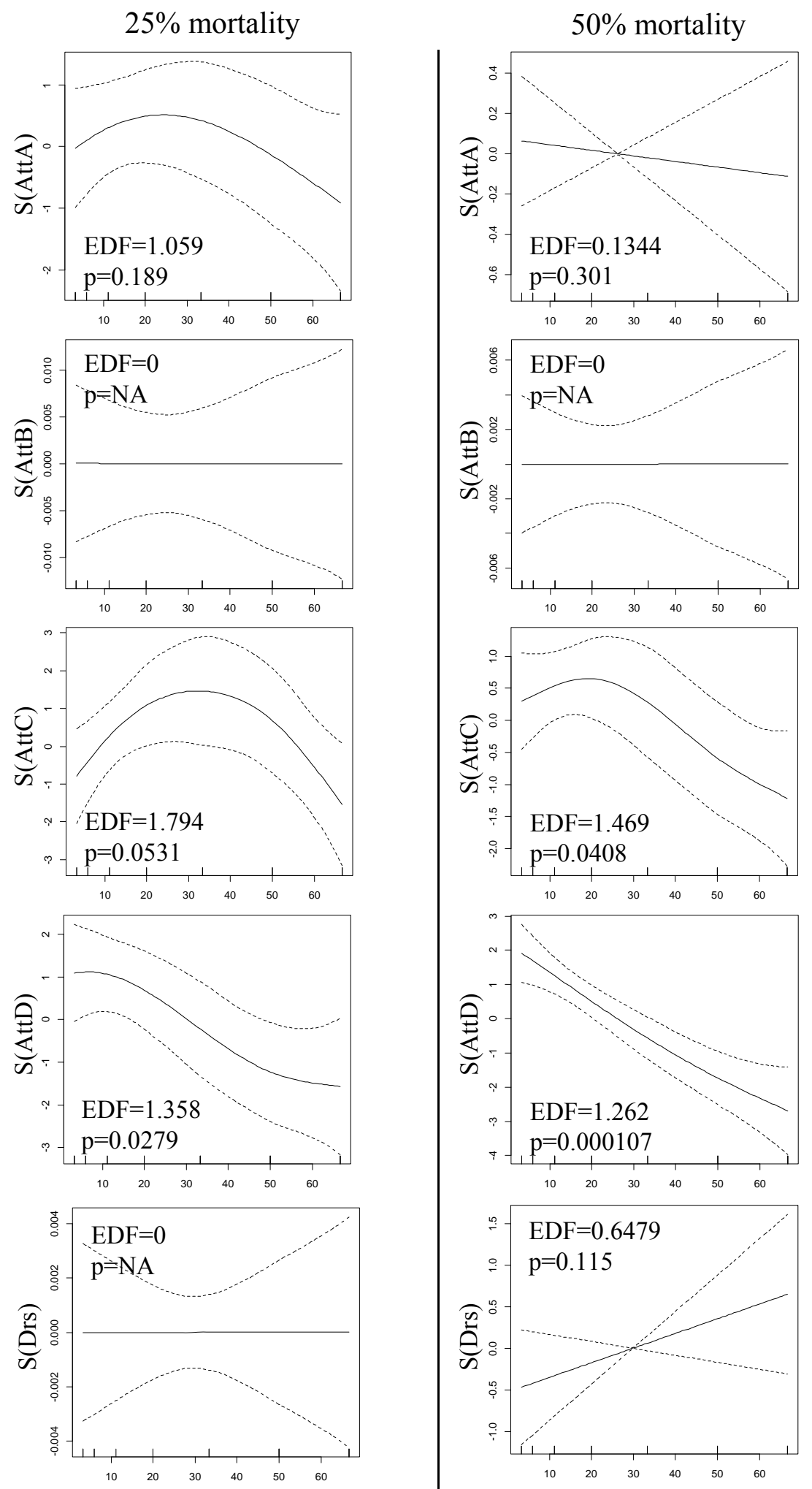

Percentage of dietary protein

Percentage of dietary protein
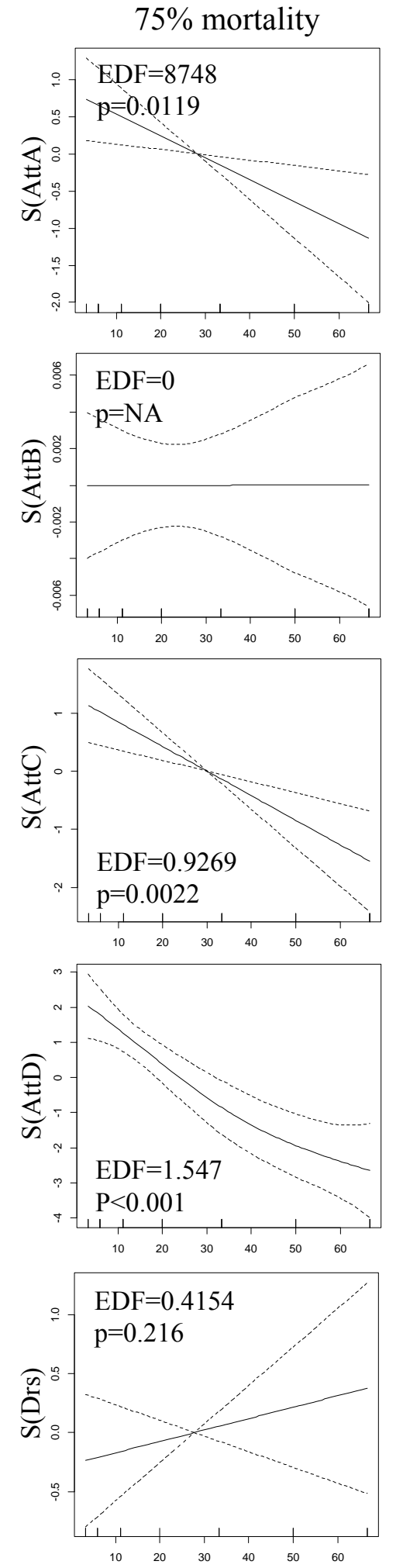

Percentage of dietary protein 
bioRxiv preprint doi: https://doi.org/10.1101/498493; this version posted December 17, 2018. The copyright holder for this preprint (which was not certified by peer review) is the author/funder, who has granted bioRxiv a license to display the preprint in perpetuity. It is made available under aCC-BY 4.0 International license.

\section{Supplementary Figure 3 (4/4) Antimicrobials}
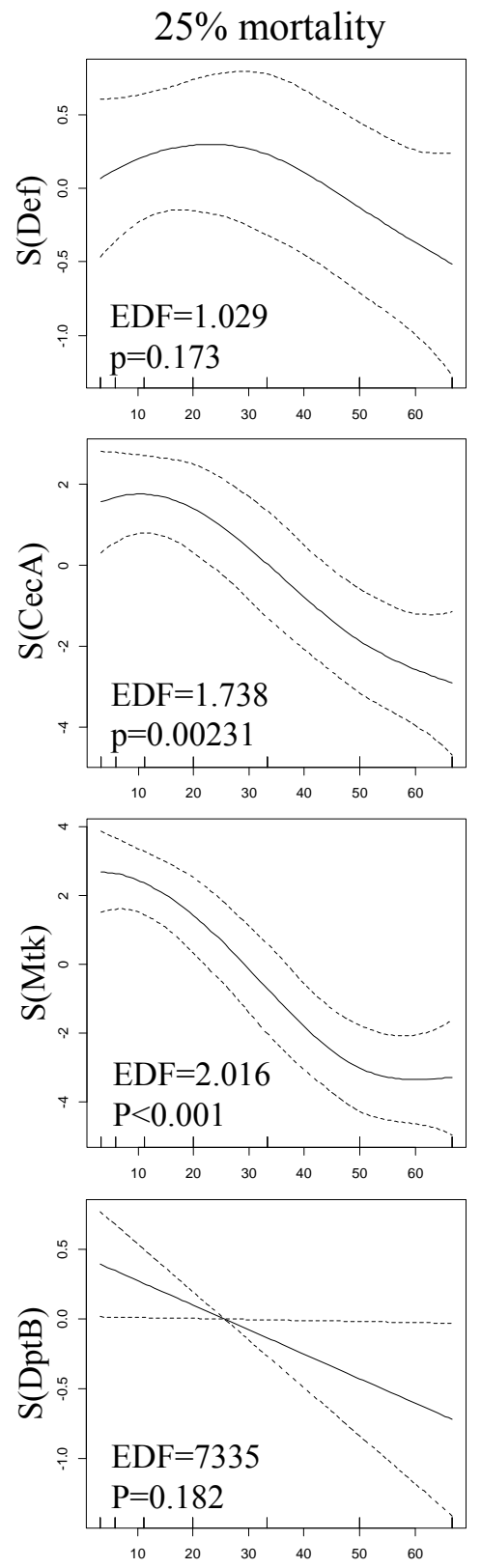

Percentage of dietary protein
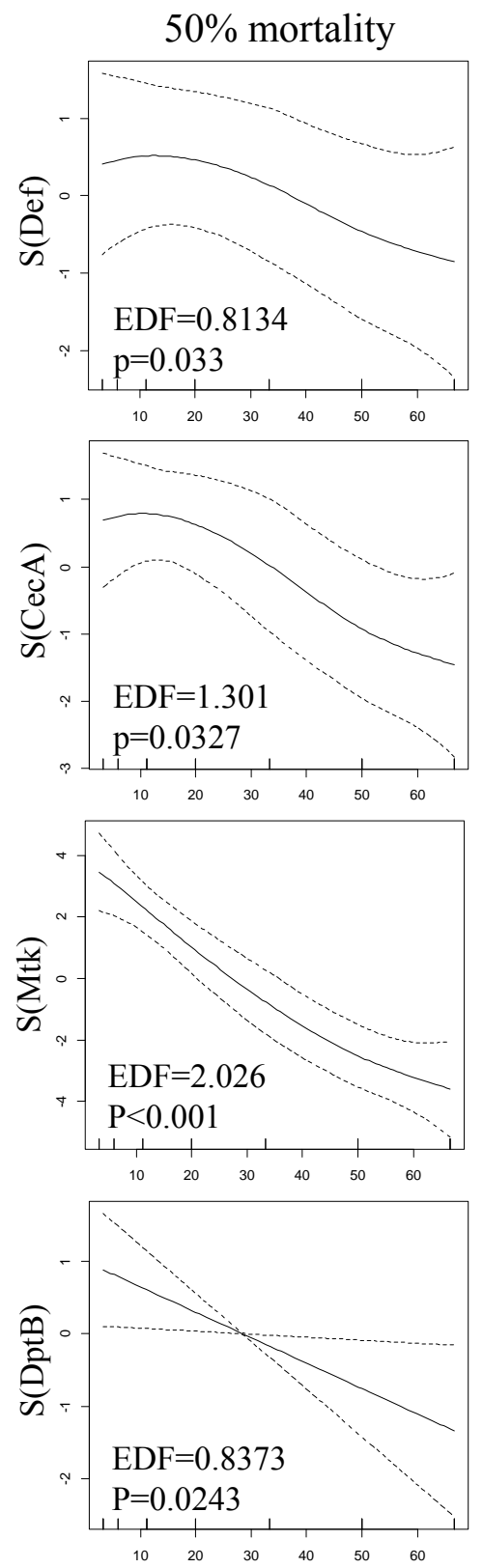

Percentage of dietary protein
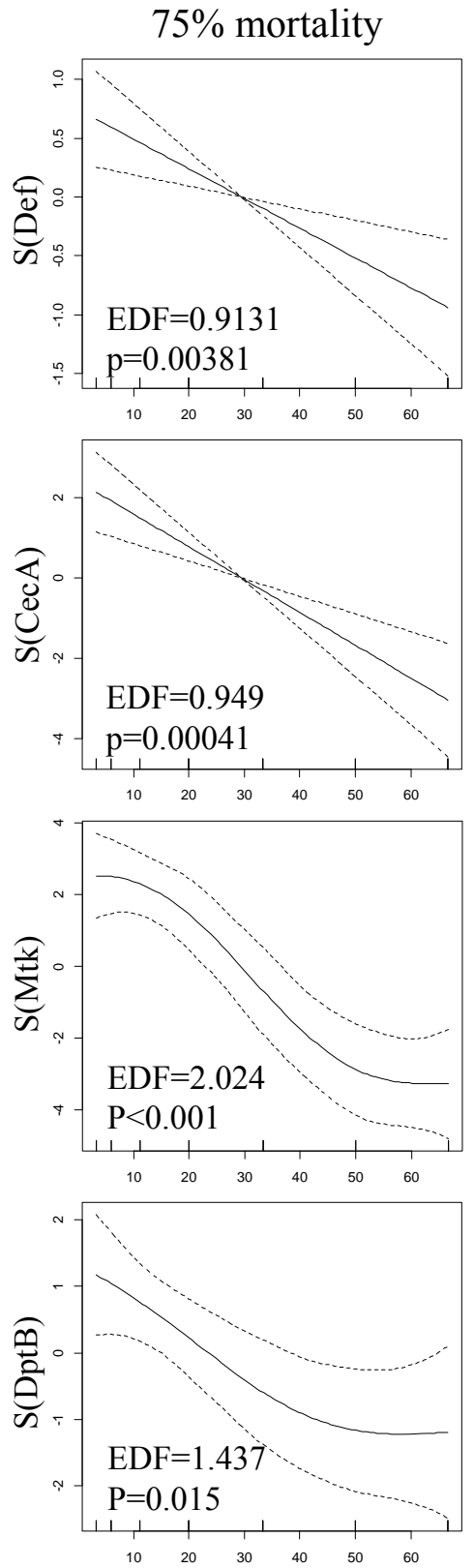

Percentage of dietary protein 
499 Supplementary Table 1. Macronutrient intakes for flies in the food choice experiment following 500 three treatments (i.e., Control, Sham- and M. luteus-infected).

501

\begin{tabular}{|c|c|c|c|c|c|}
\hline Treatment & $\begin{array}{c}\text { Total } \\
\text { carbohydrate } \\
\text { eaten }(\mu \mathrm{g})\end{array}$ & $\mathrm{SD}$ & $\begin{array}{c}\text { Total } \\
\text { protein } \\
\text { eaten }(\mu \mathrm{g})\end{array}$ & $\mathrm{SD}$ & $\mathrm{N}$ \\
\hline Naïve & 534.47 & 159.15 & 136.35 & 82.76 & 13 \\
M. luteus & 532.81 & 123.01 & 50.83 & 22.85 & 10 \\
Sham & 448.46 & 100.70 & 140.41 & 76.08 & 13 \\
\hline
\end{tabular}

502

503

504 
505 Supplementary Table 2. Gene details and statistical analyses following RT-qPCR assays.

506

\begin{tabular}{|c|c|l|}
\hline Target gene & Full name & One-way ANOVA \\
\hline GNBP2 & Gram-negative bacteria binding protein 2 & $F_{2,10}=0.062 ; p=0.941$ \\
PGRPSA & Peptidoglycan recognition protein SA & $F_{2,12}=1.321 ; p=0.314$ \\
spz & Spatzle & $F_{2,14}=42.531 ; \mathbf{p}<\mathbf{0 . 0 0 1}$ \\
Dif & Dorsal-related immunity factor & $F_{2,12}=7.546 ; \mathbf{p}=\mathbf{0 . 0 1 2}$ \\
AttA & Attacin A & $F_{2,9}=37.996 ; \mathbf{p}<\mathbf{0 . 0 0 1}$ \\
CecA1 & Cecropin A1 & $F_{2,12}=36.365 ; \mathbf{p}<\mathbf{0 . 0 0 1}$ \\
CecC & Cecropin C & $F_{2,13}=67.678 ; \mathbf{p}<\mathbf{0 . 0 0 1}$ \\
DptB & Diptericin B & $F_{2,14}=46.543 ; \mathbf{p}<\mathbf{0 . 0 0 1}$ \\
Def & Defensin & $F_{2,14}=29.390 ; \mathbf{p}<\mathbf{0 . 0 0 1}$ \\
Mtk & Metchnikowin & $F_{2,14}=30.046 ; \mathbf{p}<\mathbf{0 . 0 0 1}$ \\
\hline
\end{tabular}


508 Supplementary Table 3. A. Generalized linear model (Binomial error distribution) analyses to 509 test for the effects of diet (low, medium and high P:C ratio) and treatment (M. luteus- and sham510 infected, and naïve) on the number of dead flies after 15 days. B. Percentage of dead flies in each 511 treatment and diet after 15 days.

512

$513 \quad$ A

\begin{tabular}{|lcccc|}
\hline \multicolumn{1}{|c}{ Factors } & df & df residuals & Residuals deviance & p \\
\hline Diet & 2 & 1328 & 1260.2 & $<\mathbf{0 . 0 0 1}$ \\
Treatment & 2 & 1326 & 1213.8 & $<\mathbf{0 . 0 0 1}$ \\
Diet X Treatment & 4 & 1322 & 1191 & $<\mathbf{0 . 0 0 1}$ \\
\hline
\end{tabular}

514

515

516 B

\begin{tabular}{|ccc|}
\hline Diet & Treatment & Percentage of dead flies \\
\hline High P:C & Naïve & 97.04 \\
High P:C & Sham & 99.28 \\
High P:C & M. luteus & 94.56 \\
Medium P:C & Naïve & 21.79 \\
Medium P:C & Sham & 52.98 \\
Medium P:C & M. luteus & 62.59 \\
Low P:C & Naïve & 19.31 \\
Low P:C & Sham & 26.35 \\
Low P:C & M. luteus & 29.25 \\
\hline
\end{tabular}


518 Supplementary Table 4. List of genes used in the design of the TLDA card assay.

519

\begin{tabular}{|c|c|c|c|}
\hline Annotation & Symbol & Name & Functional group \\
\hline CG4432 & PGRP-LC & Peptidoglycan recognition protein $\mathrm{LC}$ & Pathogens recognition \\
\hline CG9681 & PGRP-SB & Peptidoglycan recognition protein SB & Pathogens recognition \\
\hline CG8995 & PGRP-LE & Peptidoglycan recognition protein LE & Pathogens recognition \\
\hline CG11709 & PGRP-SA & Peptidoglycan recognition protein SA & Pathogens recognition \\
\hline CG14745 & PGRP-SC2 & Peptidoglycan recognition protein SC2 & Pathogens recognition \\
\hline CG6895 & GNBP1 & Gram-negative bacteria binding protein 1 & Pathogens recognition \\
\hline CG8846 & Thor & Thor/4E-BP & Transduction of the immune signal \\
\hline CG5490 & $\mathrm{Tl}$ & Toll & Transduction of the immune signal \\
\hline CG5576 & Imd & Immune deficiency & Transduction of the immune signal \\
\hline CG6134 & $\mathrm{Spz}$ & Spatzle & Transduction of the immune signal \\
\hline CG1385 & Def & Defensin & AMP \\
\hline CG1365 & CecA1 & Cecropin A1 & AMP \\
\hline CG8175 & Mtk & Metchnikowin & AMP \\
\hline CG10810 & Drs & Drosomycin & AMP \\
\hline CG10794 & DptB & Diptericin B & AMP \\
\hline CG6794 & Dif & Dorsal-related immunity factor & AMP \\
\hline CG11992 & Rel & Relish & AMP \\
\hline CG10146 & AttA & Attacin A & AMP \\
\hline CG18372 & AttB & Attacin B & AMP \\
\hline CG4740 & AttC & Attacin $\mathrm{C}$ & AMP \\
\hline CG7629 & AttD & Attacin D & AMP \\
\hline CG1873 & Ef1 $\alpha 100 \mathrm{E}$ & Elongation factor $1 \alpha 100 \mathrm{E}$ & Reference gene \\
\hline CG1913 & $\alpha \mathrm{Tub84B}$ & $\alpha$-Tubulin at $84 \mathrm{~B}$ & Reference gene \\
\hline CG7939 & RpL32 & Ribosomal protein L32 & Reference gene \\
\hline FBgn0061475 & 18SrNA & 18SrNA & Reference gene \\
\hline
\end{tabular}


521 Supplementary Table 5. Sampling at 25\%, 50\% and 75\% mortality on the life expectancy

522 curves for each of the seven diets varying in the protein-to-carbohydrate ratio.

523

\begin{tabular}{|c|cc|cc|cc|}
\hline \multirow{2}{*}{ \% Protein } & \multicolumn{2}{|c|}{ 25\% mortality } & \multicolumn{2}{c|}{$\mathbf{5 0 \% \text { mortality }}$} & \multicolumn{2}{c}{$\mathbf{7 5 \% \text { mortality }}$} \\
& average (days) & SD & average (days) & SD & average (days) & SD \\
\cline { 2 - 6 } 4 & 35.67 & 13.65 & 49.00 & 5.29 & 55.00 & 2.00 \\
8 & 40.33 & 5.69 & 45.67 & 5.51 & 48.00 & 6.00 \\
14 & 25.67 & 10.69 & 35.67 & 4.62 & 39.67 & 4.04 \\
24 & 17.67 & 4.51 & 25.67 & 4.04 & 30.67 & 3.21 \\
36 & 16.00 & 4.00 & 19.33 & 4.51 & 21.67 & 3.51 \\
52 & 11.33 & 1.15 & 13.33 & 1.15 & 15.67 & 2.52 \\
62 & 7.67 & 2.52 & 10.00 & 2.65 & 11.67 & 0.58 \\
\hline
\end{tabular}

524 
525 Supplementary Table 6. Kruskal-Wallis analyses to test for the effect of the percentage of 526 dietary protein on the level of expression of immune receptors genes and genes coding for 527 molecules involved in the transduction of the immune signal.

528

\begin{tabular}{|c|c|c|c|c|}
\hline Gene class & $\chi^{2}$ & df & $p$ & $\mathrm{~N}$ \\
\hline \multicolumn{5}{|l|}{$25 \%$ mortality } \\
\hline Immune receptors & 16.599 & 6 & 0.011 & 105 \\
\hline Transduction immune signal & 12.653 & 6 & 0.049 & 126 \\
\hline \multicolumn{5}{|l|}{$50 \%$ mortality } \\
\hline Immune receptors & 13.810 & 6 & 0.032 & 110 \\
\hline Transduction immune signal & 11.097 & 6 & 0.085 & 134 \\
\hline \multicolumn{5}{|l|}{$75 \%$ mortality } \\
\hline Immune receptors & 19.336 & 6 & 0.004 & 108 \\
\hline Transduction immune signal & 5.944 & 6 & 0.429 & 125 \\
\hline
\end{tabular}


531 Supplementary Table 7. Primers of genes used in the RT-qPCR experiment.

532

\begin{tabular}{|c|c|c|}
\hline \multicolumn{2}{|c|}{ Gram-negative bacteria binding protein 2 (GNBP2, CG4144) } & \multirow{3}{*}{$\begin{array}{c}\text { Source of primer sequences } \\
\text { This study }\end{array}$} \\
\hline Primer forward & GGATTTAGCGTTTCCATACCG & \\
\hline Primer reverse & GAAGGATGTGAAATTCCGATTG & \\
\hline \multicolumn{3}{|c|}{ Peptidoglycan recognition protein SA (PGRP-SA, CG11709) } \\
\hline Primer forward & GCGATCAGGGCGTAATCCT & \multirow{2}{*}{ This study } \\
\hline Primer reverse & CTCTGGGTGCTGATCACCTG & \\
\hline \multicolumn{3}{|c|}{ Spatzle (Spz, CG6134) } \\
\hline Primer forward & ATATCGCGGCATTTCATCAG & \multirow{2}{*}{ This study } \\
\hline Primer reverse & CACGTTTGCGAGACACACAG & \\
\hline \multicolumn{3}{|c|}{ Dorsal-related immunity factor (Dif, CG6794) } \\
\hline Primer forward & TCTGTCTGACCCAGTGCATTC & \multirow{2}{*}{ This study } \\
\hline Primer reverse & TATATCGCCGAAAGCCTCCT & \\
\hline \multicolumn{3}{|c|}{ Attacin-A (AttA, CG10146) } \\
\hline Primer forward & GGCGGAACTTTGGCCTAC & \multirow{2}{*}{ This study } \\
\hline Primer reverse & AGATTGTGTCTGCCATTGTTGA & \\
\hline \multicolumn{3}{|c|}{ Cecropin A1 (CecA1, CG1365) } \\
\hline Primer forward & TTTCGTCGCTCTCATTCTGG & \multirow{2}{*}{ Zambon et al. (2005) PNAS 102: 7257-7262. } \\
\hline Primer reverse & GACAATCCCACCCAGCTTCCCGATTG & \\
\hline \multicolumn{3}{|c|}{ Cecropin C (CecC, CG1373) } \\
\hline Primer forward & TCATCCTGGCCATCAGCATT & \multirow{2}{*}{ Becker et al. (2010) Nature 463: 369-373. } \\
\hline Primer reverse & CGCAATTCCCAGTCCTTGAAT & \\
\hline \multicolumn{3}{|c|}{ Diptericin B (DptB, CG10794) } \\
\hline Primer forward & ACTGGCATATGCTCCCAATTTT & \multirow{2}{*}{ This study } \\
\hline Primer reverse & CTCAGATCGAATCCTTGCTTTG & \\
\hline \multicolumn{3}{|c|}{ Defensin (Def, CG1385) } \\
\hline Primer forward & CCACATGCGACCTACTCTCCA & \multirow{2}{*}{ Zambon et al. (2005) PNAS 102: 7257-7262. } \\
\hline Primer reverse & GACAAGAACGCAGACGGCCTTG & \\
\hline \multicolumn{3}{|c|}{ Metchnikowin (Mtk, CG8175) } \\
\hline Primer forward & CCACCGAGCTAAGATGCAA & \multirow{2}{*}{ Steckel and Boutros (2005) Biochemica 3: 17-19. } \\
\hline Primer reverse & TCTGCCAGCACTGATGTAGC & \\
\hline
\end{tabular}

